\title{
Manniindole, an indole derivative from the roots of Anonidium manniiand combined antischistosomal and enzymatic activities
}

Toussi Matchi Josette Linda ${ }^{1,2}$, Tchamo Noungoue Diderot ${ }^{1,}{ }^{*}$, Kuhn Isabelle ${ }^{2}$, Boissier Jerome ${ }^{3}$, Tchouankeu Jean Claude ${ }^{1}$, Nothisen Marc ${ }^{2}$, Chaubet Guilhem ${ }^{2}$, Garnier Delphine ${ }^{2}$, Ursuegui Sylvain ${ }^{2}$, Ngouela Silvere Augustin ${ }^{1}$, Wagner Alain ${ }^{2}$

1 Department of Organic Chemistry, Faculty of Science, University of Yaoundé I, Yaoundé, Cameroon

2 Laboratoire de Chimie Bio-Fonctionnelle, UMR 7199 CNRS, Faculty of Pharmacy, University of Strasbourg, Illkirch Cedex, France

3 Interactions Hôtes-Pathogenes- Environnements, UMR 5244 CNRS, University of Perpignan, Perpignan, France

*Corresponding author : Diderot Tchamo Noungoue, email address : didetchamo@yahoo.fr

\begin{abstract}
:
A new alkaloid, manniindole1, together with four known compounds: aristolactam All2, aristolactam BII3, piperolactam D4and polycarpol5were isolated from the crude extract $\mathrm{EtOH}-\mathrm{H} 2 \mathrm{O}$ (8:2) of the roots ofAnonidium manniiby chromatographic separation. The structure elucidation was performed on the basis of a spectroscopic analysis (IR, HRESI MS, 1D and 2D NMR) as well as a comparison of their spectral data with those reported in the literature. For the first time, the crude extract and those isolated compounds were evaluated for their anti-schistosomal activity againstSchistosoma mansoniand for cytotoxicity activity against Huh7 and A549 cells. Furthermore, they were also testedin vitroon the recent characterizedSchistosoma mansoniNAD $(+)$ catabolizing enzyme (SmNACE) for their impact on this enzyme which is localized on the outer surface of the adult parasite. Compound2displayed quite good worm killing capability, while4showed significant inhibition ofSmNACE.
\end{abstract}




\section{Graphical abstract}
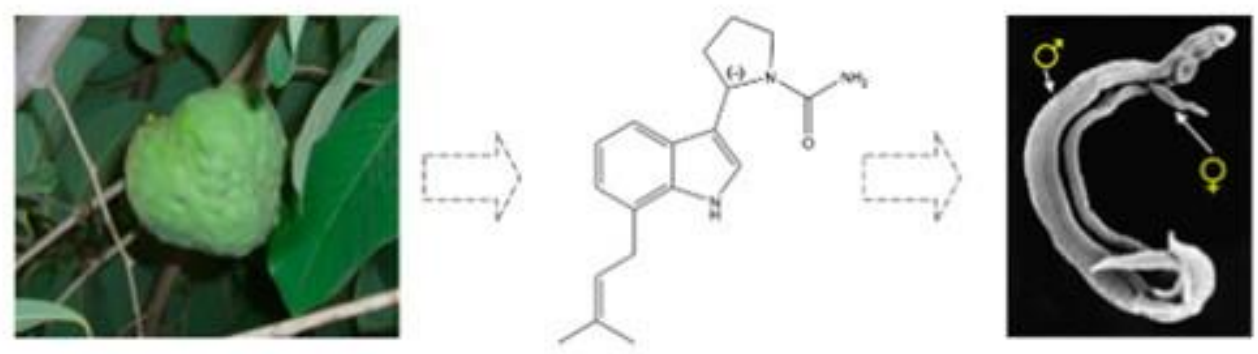

Keywords : Anonidium mannii, Annonaceae, phytochemical and biological investigation, indole alkaloid, anti-schistosomal activity, enzymatic activity (SmNACE), cytotoxicity 


\section{Introduction}

The genus Anonidium, belonging to the Annonaceae family, comprises 7 tropical African tree and shrub species (Pellegrin 1947), but this genus is not well studied. Anonidium mannii (Oliv.) Engl. \& Diels, is known to be located to Central Africa [Cameroon (Bankomo, Makenene, Ndikinemeki, Kribi), Gabon and Congo], and has been used in the respective countries of origin for the treatment of various ailments including female infertility (Abondo et al. 1991), treatment of abscess (Taffou et al. 2017), open wounds, hemorrhoids, intestinal spasms, diarrhea (Musuyu Muganza et al. 2012), arthritis, rheumatism, dysentery, paralysis, epilepsy, convulsion, stomach trouble (Erhenhi and Obadoni 2015), cancer (Kuete et al. 2013) malaria (Betti 2004) and Schistosomiasis (Messi 1999). Otherwise, Schistosomiasis, also known as bilharzia, is a disease caused by parasitic worms infecting people worldwide. This neglected tropical disease (OMS 2010; Zhang et al. 2010) comes second after malaria as the most devastating parasitic disease in terms of impact. It is estimated that 600 million people are at risk of infection, 200 million people are infected, and at least 200 thousand deaths per year are associated with the disease (OMS 2014). The parasites that cause schistosomiasis live in certain types of freshwater snails, from which their infectious form, known as cercariae, can emerge into the water and infect humans through skin contact. In most human infections, acute schistosomiasis is caused by Schistosoma mansoni, S. haematobium, or S. japonicum, and is characterized by fever, headache, myalgia, and respiratory symptoms, and occasionally by eosinophilia and painful hepato-and/or splenomegaly. No vaccine is currently available and the antiparasitic drug mostly used to treat schistosomiasis is Biltricide, which active ingredient (Praziquantel) belongs to the alkaloid family (OMS 2020; Doenhoff et al. 2009). However, it is only effective against adult worms and it has showed many side effects. More worrying, because the question of the reduction of the efficacy of praziquantel molecule was raised recently, it is thus urgent to find new, safe antischistosomal drugs and new therapeutic targets (Fallon and Doenhoff 1994). SmNACE is an ecto-enzyme recently discovered which has a favorable topology because it is one of the rare identified and characterized target on the tegument of adult schistosomes responsible for serious clinic troubles. In fact, SmNACE is extremely interesting due to its accessibility of drugs and thus a potential target for conception of future therapeutic agents (Goodrich et al. 2005; Kuhn et al. 2010; Jacques et al. 2015).

The Annonaceae family is known to contain acetogenins, alkaloids, essential oils, terpenoids, and some flavonoids (Leboeuf 1982). Previous phytochemical investigation on the specie Anonidium mannii revealed the presence of alkaloids, phenols, polyphenols, saponins, tannins and steroids (Djeussi et al. 2013; Ngangoue et al. 2020). Some prenylated indoles and bisindole alkaloids have been identified from the stem bark of A. mannii (Achenbach and Renner 1985) and some have been reported to have the following biological activities: antibacterial, immunosuppressive and radical scavenging (Southon and Buckingham 1989). As a part of our ongoing project on the structurally and biologically interesting secondary metabolites from Anonidium mannii, and based on previous reports on the antiparasitic activity of this species, the aim of this work was to carry out a phytochemical and biological investigation on the roots of the plant collected from Cameroon.

\section{Results and discussion}

Herein report the isolation and characterization by the spectroscopies means, of the novel indole derivative 1, together with four known compounds identified as, aristolactam A II 2 (Sun et al. 1987), aristolactam B II 3 (Akasu et al. 1974), piperolactam D 4 (Desai et al. 1990) and polycarpol 5 (Hammonière et al. 1976) respectively (Figure 1); and also their cytotoxicity, enzymatic and antischistosomal activities evaluation

Compound 1 was isolated as a yellow-orange amorphous powder, which gave a positive Dragendorff test characteristic of alkaloid. Its molecular formula $\mathrm{C}_{18} \mathrm{H}_{23} \mathrm{~N}_{3} \mathrm{O}$, could be deduced 
from its positive high resolution electrospray ionization mass spectrum (HRESI-MS) which showed protonated molecule $[\mathrm{M}+\mathrm{H}]^{+}$ion peak at $\mathrm{m} / \mathrm{z}$ 298. 1924 (calc. 298. 1919), indicating nine degrees of unsaturation. Its infrared spectrum displayed maxima at around $3480 \mathrm{~cm}^{-1}$ which could be due by a vibration of the $\mathrm{N}-\mathrm{H}$ group for a indole skeleton (Benesova et al. 1969), and we can also observe absorptions attributable to the N-carbamoylpyrrolidine at $\left(\mathrm{cm}^{-}\right.$ 1) 3270 and $3100\left(\mathrm{NH}_{2}\right)$; 1651 (amid carbonyl, $\mathrm{N}_{2} \mathrm{C}=\mathrm{O}$ ); 1519, $1494(\mathrm{~N}-\mathrm{CO}-\mathrm{N})$ (D'Ambrosio et al. 1986).

The ${ }^{13} \mathrm{C}$ NMR spectrum (Table S1) displayed 18 carbon signals which were sorted by DEPT into two methyls, four $\mathrm{sp}^{3}$ methylenes, six methines (three aromatics, two olefinics and one $\mathrm{sp}^{3}$ ) five $\mathrm{sp}^{2}$ quaternary carbons and one carbonyl at $\delta_{\mathrm{c}} 157.2$ characteristic of $\mathrm{N}$-carbamoyl group.

The ${ }^{1} \mathrm{H}$ NMR spectrum of $\mathbf{1}$ (Table S1) showed in the low field region, two broad singlets at $\delta_{\mathrm{H}} 10.80$ and 7.03 which might confirm the existence in $\mathbf{1}$ of an indoyl N-H and olefinic $(\mathrm{H}-$ 2) protons respectively (Benesova et al. 1969), and furthermore it exhibited also three coupled aromatic protons each other at $\delta \mathrm{H} 7.34(1 \mathrm{H}, \mathrm{bd}, J=7.8 \mathrm{~Hz}, \mathrm{H}-4), \delta \mathrm{H} 6.90(1 \mathrm{H},(1 \mathrm{H}, \mathrm{t}, J=7.5 \mathrm{~Hz}$, $\mathrm{H}-5)$ and $\delta_{\mathrm{H}} 6.85(1 \mathrm{H}, \mathrm{bd}, J=7.0 \mathrm{~Hz}, \mathrm{H}-6)$, this assume that the single aromatic cycle of 1 was trisubstituted. In addition, this spectrum showed the characteristic resonances of a 3,3dimethylallyl moiety $\left[\delta_{\mathrm{H}} 1.71(6 \mathrm{H}, \mathrm{s}, \mathrm{H}-4\right.$ "' and H-5' '); $3.50(2 \mathrm{H}, \mathrm{d}, J=7.4 \mathrm{~Hz}, \mathrm{H}-1$ ' ') and 5.43 $(1 \mathrm{H}, \mathrm{m}, \mathrm{H}-2$ '' $]$. After all, we can also observe aliphatic protons at $\delta_{\mathrm{H}}[1.86(2 \mathrm{H}, \mathrm{m}, \mathrm{H}-3$ ' $) ; 1.89$ $(1 \mathrm{H}, \mathrm{m}, \mathrm{H}-4 \mathrm{a}), 2.17(1 \mathrm{H}, \mathrm{m}, \mathrm{H}-4 \mathrm{~b}) ; 3.43(1 \mathrm{H}, \mathrm{m}, \mathrm{H}-2 \mathrm{a}) ; 3.51(1 \mathrm{H}, \mathrm{m}, \mathrm{H}-2 \mathrm{~b})$ and $5.11(1 \mathrm{H}, \mathrm{bd}$, $\left.\left.J=7.2 \mathrm{~Hz} ; \mathrm{H}-5^{\prime}\right)\right]$, together with amide protons $\left(\mathrm{CONH}_{2}\right)$ at $\delta \mathrm{H} 5.45(2 \mathrm{H}, \mathrm{s}$,$) ; According to its$ molecular formula, all these data corroborate the presence in the compound $\mathbf{1}$ of a $\mathrm{N}$ carbamoylpyrrolidine group. Combined analysis of these data above indicated that compound 1 had a framework of an indole type alkaloid which was substituted by prenyl and Ncarbamoylpyrrolidine groups respectively. In its ${ }^{1} \mathrm{H}-{ }^{1} \mathrm{H}$ COSY spectrum, coupling was observed between olefinic proton ( $\mathrm{H}-2)$ and $\mathrm{N}-\mathrm{H}$ proton of the pyrrole ring of the indole moiety and this assume that $\mathrm{C}-3$ was substituted, and associate with the $\mathrm{HMQC}$, that spectrum revealed connectivity of pyrrolidine ring (C-2', C-3', C-4' and C-5' resp.) and prenyl group (C-1' ', C2 "' and C-4"'/5" resp.). Key HMBC correlations between aliphatic protons (H-2" and H-1") of the 3,3-dimethylallyl moiety and aromatic carbons (C-7 and C-6; C-7a resp.) of the indole skeleton allowed us to fix the prenyl group on $\mathrm{C}-7$, and interaction between $\mathrm{H}-5$ ' and $\mathrm{C}-2$ enabled us to attach N-carbamoylpyrrolidine on carbon C-3. This was confirmed by its NOESY correlations observed between $\mathrm{H}-5$ ' and $\mathrm{H}-2$ and $\left(\mathrm{CON}_{2}\right)$ protons respectively (Figure $\mathrm{S} 2$ ). The compound 1 was showed optical activity, due to its chiral carbon (C-5) which deflected the polarized light to the left (levorotatory) based on the polarimetry performed. Hence, its structure was identified as (-)-3-(5'-N-carbamoylpyrrolidine)-7- (3''-methyl-2''-butenyl) indole and has been given the trivial name manniindole.

In the meantime, new compound 1, and compounds 2, 3 and 4 were subjected to antischistosomal, enzymatic and/or cytotoxicity activities, the results were quite encouraging.

The human lung cancer cells (A549) and the human hepatocarcinoma cells (Huh7) were chosen for evaluating the cytotoxicity of compound 1 due to the fact that the lung and liver are the focal points of pathogenic insult and subsequent pathological damage in schistosomiasis (De Oliveira et al. 2013). At the concentration $\mathrm{C}=100 \mu \mathrm{M}$, the percentage of cell viability is about 15\% (Huh7 cells) and 80\% (A549 cells). This showed that the compound 1 was toxic at this concentration for Huh7 cells line and no toxic for A549 cells line (Figure S3).

The new compound $\mathbf{1}$ and the compounds $\mathbf{2}$ and $\mathbf{3}$ were evaluated in vitro for their activity against adult Schistosoma mansoni. Only compound $\mathbf{2}$ displayed quite good worm killing capability after $6 \mathrm{~h}$ at the concentrations of $100 \mu \mathrm{M}$, Praziquantel was taken as positive control (Table S2). 
The compounds 1, 2, 3 and 4 were also tested for their ability to inhibit the catalytic activity of recombinant SmNACE in vitro using $1, \mathrm{~N}^{6}$-etheno $\mathrm{NAD}^{+}$as substrate. This enzyme was chosen due to its expression on the outer surface of the Schistosoma mansoni adult worm tegument. In these sense, it could be an interesting pharmacological target for antischistosomal therapy (Goodrich et al., 2005). The IC 50 values were determined fluorometrically using $1, \mathrm{~N}^{6}$ etheno $\mathrm{NAD}^{+}$as substrate. Only the compound $\mathbf{4}$ showed a significant inhibition with a $\mathrm{IC}_{50}$ value about 10-20 $\mu \mathrm{M}$ compared to the reference SmNACE inhibitor (Table S3).

\section{Experimental}

\subsection{General methods}

IR spectrum was obtained using a Thermo Electron (Nicolet 380) FT-IR spectrometer. Column chromatography was carried out using silica gel (Merck 60-120, 70-230 and 230-400 mesh). Rotating power was recorded on a P-2000 Jasco polarimeter. Thin layer chromatography was performed on percolated $0.5 \mathrm{~mm}$ thickMerck Si gel 60 F254 aluminium sheets. Separated compounds were visualized under UV light and by spraying with $\mathrm{H}_{2} \mathrm{SO}_{4}-\mathrm{EtOH}(1: 9$, v/v) followed by mild heating for about 2-3 min. The mass spectra were recorded on an Agilent MS instrument (Agilent Technologies 6520, Accurate mass Q-Tof). NMR spectra were recorded on a Bruker Avance DRX-500 instrument operating at $500 \mathrm{MHz}\left({ }^{1} \mathrm{H}\right)$ and $125 \mathrm{MHz}\left({ }^{13} \mathrm{C}\right)$, using a deuterated dimethylsulfoxyde (DMSO- $\left.d_{6}\right)$ as solvent. Chemical shifts $(\delta)$ were quoted in parts per million (ppm) from internal standard tetramethylsilane (TMS) and the coupling constants $(J)$ are given in Hz. Different mixtures of n-hexane, EtOAc, $\mathrm{CH}_{2} \mathrm{Cl}_{2}$ and $\mathrm{MeOH}$ were used as eluting solvents. They were distilled prior to use.

\subsection{Plant material}

Roots of Anonidium mannii were collected in 2016 at Mount Kalla (Latitude $3^{\circ} 30^{\prime}$. North, Longitude $11^{\circ} 13^{\prime}$. East), from Bankomo locality, Mefou et Akono Sub-division, Center Region of Cameroon and identified by M. Victor NANA, a botanist of National Herbarium, Yaounde, Cameroon; where a voucher specimen is deposited under the voucher number $45582 \mathrm{HNC}$.

\subsection{Extraction and isolation}

The air-dried and powdered roots $(3.4 \mathrm{~kg})$ of $A$. mannii was macerated in $25 \mathrm{~L}$ of a mixture of EtOH- $\mathrm{H}_{2} \mathrm{O}(8: 2)$ for $72 \mathrm{~h}$ at room temperature. After filtration and solvent evaporation, a residue of $130.41 \mathrm{~g}$ was obtained. A part of the crude extract (100 g) was subjected to flash column chromatography (FCC) on silica gel employing a step gradient of hexane-ethyl acetate and ethyl acetate-methanol to afford ten fractions Fr1-Fr10 based on TLC monitoring.

Fraction Fr6 (2.51 g) was purified employing a step gradient of hexane (1:0)-ethyl acetate (7:3) to yield polycarpol $5(15.0 \mathrm{mg})$. A part of the fraction Fr9 $(3.24 \mathrm{~g})$, eluted with a gradient dichloromethane (1:0)-methanol (9.5:0.5) lead to aristolactam AII 2 (8mg). Fraction Fr10 (9.1 g) was purified by flash chromatography (MPLC) over silica gel with a gradient ethyl acetate (1:0)-methanol (8.5:1.5) and subfractions [30-55] (250mg) were purified by semi-preparative HPLC using a gradient $(5-95 \% \mathrm{CH} 3 \mathrm{CN}$, in $60 \mathrm{~min})$ to give piperolactam D $4(11.2 \mathrm{mg})$, aristolactam BII 3 (12mg) and manniindole (1) (6mg). For ${ }^{1} \mathrm{H}$ and ${ }^{13} \mathrm{C}$ NMR data, see Table S2.

3.4. Bioassay

\subsubsection{Cytotoxicity activity}


Cytotoxicity was tested against the Huh7 and A549 cells using a MTS assay. Huh7 cells (Human Hepato carcinoma cells) are cultured in DMEM medium $1 \mathrm{~g} / \mathrm{L}$ glucose (SIGMA), $2 \mu \mathrm{M}$ Glutamine and 10\% FCS (fetal calf serum, SIGMA). The A549 cells (Human Lung Tumor cells) are cultured in HamF12 medium, $2 \mu \mathrm{M}$ Glutamine and 10\% FCS. 24 hours before the toxicity experiment, the cells are seeded in a 96-well plate (Nunc Edge 2.0, ThermoScientific) at the rate of 4000 cells/well (Huh7); 6000 cells/well (A 549) in $100 \mu \mathrm{L}$ and cultured in an incubator at $37^{\circ} \mathrm{C}$. with $5 \% \mathrm{CO}_{2}$. The extracts to be tested are diluted in medium with serum and added at a rate of $20 \mu \mathrm{L} /$ well to obtain the desired final concentration. All tests were done in triplicate. 48 hours after the addition of the extracts, $20 \mu \mathrm{L}$ of MTS solution (Cell Titer $96 \mathrm{R}$ Aqueous One Cell Proliferation Assay Solution, Promega) are added to each well. After 1 hour of incubation at $37^{\circ} \mathrm{C}$., the ODs are read at $490 \mathrm{~nm}$ and $700 \mathrm{~nm}$ (Safas, Monaco).

The OD or absorbance of the extracts to be assayed $(490 \mathrm{~nm})$ are analyzed after deducting the OD at $700 \mathrm{~nm}$, the OD of the plastic, the OD of the cells alone.

Praziquantel and DMEM medium were used as positive and negative controls, respectively.

\subsubsection{Determination of activity against adult Schistosoma mansoni (in vitro)}

The host-parasite system used was an albino variety of Biomphalaria glabrata from Brazil and a strain of Schistosoma mansoni from Puerto Rico (NMRI strain). Female hamsters (Mesocricetus auratus; Janvier Labs; Le genest-Saint-Isle, France) were percutaneously exposed to 400 cercariae following standard procedures previously published (Dumont et al. 2007). Forty days' post-exposition adult S. mansoni were recovered from the hepatic portal system and mesenteric veins by hepatic perfusion technique (Boissier et al. 2003). Living worms were immediately deposited in RPMI 1640 culture medium (supplemented with 5\% inactivated foetal calf serum (iFCS) and $100 \mathrm{U} / \mathrm{mL}$ penicillin and $100 \mu \mathrm{g} / \mathrm{mL}$ streptomycin (Invitrogen, Carlsbad, CA) at $37^{\circ} \mathrm{C}$ in an atmosphere of $5 \% \mathrm{CO}_{2}$. Ten to twelve worms with equilibrated sex ratio were deposited in each well of 24 well plates. For the determination of activity against adult flukes all compounds were initially tested at a concentration of $100 \mathrm{lg} / \mathrm{mL}$, using DMSO stock solutions (conc $10 \mu \mathrm{g} / \mathrm{mL}$; final concentration of DMSO: 0.2 ) diluted in supplemented RPMI 1640 medium with a final volume of $2 \mathrm{~mL}$ per well. Wells with RPMI and DMSO in medium served as negative controls. PZQ served as positive control, and concentrations of 10,50 , and $100 \mu \mathrm{g} / \mathrm{mL}$ were used to evaluate the shistosome's mortality. Each test was performed in duplicate or triplicate. Parasites were subsequently observed for body contractility and movement each hour for 6 hours. Parasites showing no body contractions during a $30-\mathrm{s}$ observation were considered dead [no worm started to move again after $30 \mathrm{~s}$ without motor activity (Boissier et al. 2009)].

\subsubsection{Enzymatic activity (in vitro)}

SmNACE activity was determined by a fluorometric assay using $1, \mathrm{~N}^{6}$-etheno $\mathrm{NAD}^{+}(\varepsilon-$ $\mathrm{NAD}^{+}$, Sigma) as substrate. This assay consists in measuring the appearance of the reaction product $\varepsilon$-ADP-ribose by the increase of fluorescence at $\kappa e m=410 \mathrm{~nm}(\kappa e x c=310 \mathrm{~nm})$ at $37^{\circ} \mathrm{C}$ in $10 \mathrm{mM}$ potassium phosphate buffer, $\mathrm{pH} 7.4$, containing $0.05 \%(\mathrm{w} / \mathrm{v})$ emulphogen $(1 \mathrm{~mL}$ final volume) in a quartz tank.

In the spectrofluorimeter (Shimadzu RP-5301 PC), the buffer was added to the tank at $37^{\circ} \mathrm{C}$ and with stirring. The substrate was then added; its final concentration being $20 \mu \mathrm{M}$. After that, inhibitors were introduced. Before introducing the enzyme, the tracing was started in order to see the basic fluorescence $F_{0}$. Once the enzyme has been added, the kinetics were exploited at the end of the measurement time ( 2 minutes) using a non-linear regression program 
(GraphPad, Prism) for the determination of catalytic activity. All the inhibitors were initially tested at a concentration of $100 \mathrm{mM}$ diluted in DMSO (less than $2 \%$ added). In case that we observed fluorescence or quenching, the concentrations were decreased. So, concentrations of $10 \mu \mathrm{M}, 100 \mu \mathrm{M}, 1 \mathrm{mM}, 10 \mathrm{mM}$ and $100 \mathrm{mM}$ were used. Each test was performed twice.

The approximate $\mathrm{IC}_{50}$ values were determined based on concentrations giving approximately $50 \%$ inhibition.

\section{Conclusion}

In conclusion, phytochemical and biological investigation which was carried out on the roots of Anonidium mannii led to the isolation of five major compounds among which one, $\mathbf{1}$, was newly described. Though there are well known in the Annonaceae family, this is the first time that lactams were found in A. mannii. Those isolated compounds were submitted for the first time to the combined biologic tests on the schistosomes (parasitical and enzymatical tests). Two compounds, respectively $\mathbf{2}$ and $\mathbf{4}$, were potentially having good activity on adult Schistosoma mansoni in vitro and good inhibition of a new member of the ADP-ribosyl cyclase family of enzymes (SmNACE) in the Platyhelminthes trematodes, Schistosoma mansoni and Schistosoma japonicum.

\section{Acknowledgments}

The authors are thankful to AUF for providing a fellowship to J L T M.

\section{Disclosure statement}

No potential conflict of interest was reported by the author(s).

\section{Ethic statement}

The laboratory where the experiments were done has permission A66040 from «Ministère de l'Enseignement supérieur de la Recherche et de l'Innovation (France)» for animal experimentation. Experimenters possess the certificate for animal experimentation (authorization 007083, decree 87-848 and 2012201-0008). Housing, breeding and animal care followed the national and European ethical requirements. 


\section{References}

Abondo A, Mbenkum F, Thomas D. 1991. Traditional medicinal plants. Dar Es Salaam University Press - Ministry of Health - Tanzania. p. 391.

Achenbach H, Renner C. 1985. Constituents of West African medicinal plants. XVIII: The Annonidines - A new class of prenylated bisindole alkaloids from Anonidium mannii. Heterocycles - Elsevier. 23(8):2075.

Akasu M, Itokawa H, Fujita M. 1974. (Aristolactam BII). Tetrahedron Lett. 15(41):3609_ 3612 .

Benesova V, Samek Z, Herout V, Sorm F. 1969. Isolation and structure of two new indole alkaloids from Riccardia sinuata (HOOK.) Trev. Institute of Organic Chemistry and Biochemistry, Czechoslovak Academy of Sciences.

Betti B. 2004. An ethnobotanical study of medicinal plants among the Baka Pygmies in the Dja Biosphere Reserve, Cameroon. Afr Study Monogr. 25:1-27.

Boissier J, Chlichlia K, Digon Y, Ruppel A, Mon_e H. 2003. Preliminary study on sex related inflammatory reactions in mice infected with $\bar{S}$ chistosoma mansoni. Parasitol Res. 91(2):144-150.

Boissier J, Cosledan F, Robert A, Meunier B. 2009. In vitro activities of trioxaquines against Schistosoma mansoni. Antimicrob Agents Chemother. 53(11):4903-4906.

D’Ambrosio M, Guerriero A, Pietra F. 1986. Carbamoylpyrrolidine and 7Chlorocavernicolenone, Two new metabolites of the Mediterranean sponge Aplysina (=Verongia) cavernicola. Comp. Biochem. Physiol. 83:309-312.

De Oliveira RB, Senger MR, Vasques LM, Gasparotto J, D, Santos, JP, Pasquali MA, Moreira JC, Silva FP, Jr, Gelain DP. 2013. Schistosoma mansoni infection causes oxidative stress and alters receptor for advanced glycation end product (RAGE) and tau levels in multiple organs in mice. International J. Parasitol. 43(5):371-379.

Desai SJ, Chaturvedi R, Mulchandani NB. 1990. Piperolactam D, a New Aristolactam from Indian Piper Species. J Nat Prod. 53(2):496-497.

Djeussi DE, Noumedem JAK, Seukep JA, Fankam AG, Voukeng IK, Tankeo SB, Nkuete AHL, Kuete V. 2013. Antibacterial activities of selected edible plants extracts against multidrug-resistant Gram-negative bacteria. BMC Complement Altern Med. 13:164-169.

Doenhoff MJ, Hagan P, Cioli D, Southgate V, Pica-Mattoccia L, Botros S, Coles G, Tchuem Tchuent_e LA, Mbaye A, Engels D. 2009. Praziquantel: its use in control of schistosomiasis in sub-Saharan Africa and current research needs. Parasitology. 136(13):18251835.

Dumont M, Mon e H, Mouahid G, Idris MA, Shaban M, Boissier J. 2007. Influence of pattern of exposure, parasite genetic diversity and sex on the degree of protection against reinfection with Schistosoma mansoni. Parasitol Res. 101(2):247-252.

Erhenhi AH, Obadoni BO. 2015. Known medicinal and aphrodisiac plants of Urhonigbe forest reserve, Edo State, Nigeria. J Med Plants Stud. 3:101-106.

Fallon PG, Doenhoff MJ. 1994. Drug-resistant schistosomiasis: resistance to praziquantel and oxamniquine induced in Schistosoma mansoni in mice is drug specific. Am J Trop Med Hyg. 51(1):83-88.

Goodrich SP, Muller-Steffner H, Osman A, Moutin MJ, Kusser K, Roberts A, Woodland DL, Randall TD, Kellenberger E, LoVerde PT, et al. 2005. Production of calcium-mobilizing metabolites by a novel member of the ADP-ribosyl cyclase family expressed in Schistosoma mansoni. Biochemistry. 44(33):11082-11097.

Hammoni_ere M, Fournet A, Leboeuf M, Bouquet A, CavB A. 1976. Polycarpol. C. R. Acad. Scz. Paris. 242:1045. 
Jacques SA, Kuhn I, Koniev O, Schuber F, Lund FE, Wagner A, Muller-Steffner H, Kellenberger E. 2015. Discovery of potent inhibitors of Schistosoma mansoni NAD catabolizing enzyme. J Med Chem. 58(8):3582-3592.

Kuete V, Fankam AG, Wiench B, Efferth T. 2013. Cytotoxicity and modes of action of the methanol extracts of six Cameroonian medicinal plants against multidrug-resistant tumor cells. Evid Based Complement Alternat Med. 2013:285903. http://dx.doi.org/10.1155/2013/285903.

Kuhn I, Kellenberger E, Said-Hassane F, Villa P, Rognan D, Lobstein A, Haiech J, Hibert M, Schuber F, Muller-Steffner H. 2010. Identification by high-throughput screening of inhibitors of Schistosoma mansoni $N A D(+)$ catabolizing enzyme. Bioorg Med Chem. 18(22):7900-7910.

Leboeuf M, Cave A, Bhaumik PK, Mukherjee B, Mukherjee R. 1982. The phytochemistry of the annonaceae. Phytochemistry. 21(12):2783-2813.

Messi M. 1999. Contribution à l'étude des plantes médicinales du Cameroun: le cas des plantes utilisées en médecine traditionnelle pour le traitement des maladies parasitaires. Thèse doctorat 3e cycle, Université de Yaoundé I.

Musuyu Muganza D, Fruth BI, Nzunzu Lami J, Mesia GK, Kambu OK, Tona GL, Cimanga Kanyanga R, Cos P, Maes L, Apers S, et al. 2012. In vitro antiprotozoal and cytotoxicactivity of 33 ethonopharmacologically selected medicinal plants from Democratic Republic of Congo. J. Ethnopharmacolog. 141(1):301-308.,

Ngangoue MO, Ngameni B, Ambassa P, C, Fru G, Wamba Nougan BE, Ombito Omollo J, Bojase Moleta G, Fotso Wabo G, Kuete V, Ngadjui Tchaleu B. 2020. A phenanthridin-6(5H)one derivative and a lanostane-type triterpene with antibacterial properties from Anonidium mannii (Oliv). Engl. \& Diels (Annonaceae). Nat Prod Res.1-10. https://doi.org/10.1080/14786419.2020.1758094

OMS. 2020. Schistosomiasis. Consulted online the 15 May 2020.

OMS. 2014. Schistosomiase (Bilharziose). Aide-mémoire N_115. Genève.

OMS. 2010. Agir pour réduire l'impact mondial des maladies tropicales négligées: premier rapport de l'OMS sur les maladies tropicales négligées. Genève.

Pellegrin F. 1947. Les Annonacées du Gabon. Bulletin de la Société Botanique de France. 94(7-8): 253-258. 8,

Southon IW, Buckingham J. 1989. Dictionary of alkaloids. Chapman and Hall/CRC. London \& New York.

Sun NJ, Antoun M, Chang CJ, Cassady JM. 1987. Aristolactam A II. J Nat Prod. 50(5):843-846.

Taffou T, Hzounda Fokou JB, Zeuko'o Menkem E, Tchokouaha Yamthe LR, Ngoutane Mfopa A, Kamdem MS, Ngouana V, Kenfack Tsague IF, Boyom FF. 2017. Anti-yeast potential of some annonaceae species from Cameroonian biodiversity. Int J Bio Chem Sci. 11(1):15-31. ISSN 1997-342X (Online).

Zhang Y, MacArthur C, Mubila L, Baker S. 2010. Control of neglected tropical diseases needs a long-term commitment. BMC Med. 8(1):67. 
Abstract figure
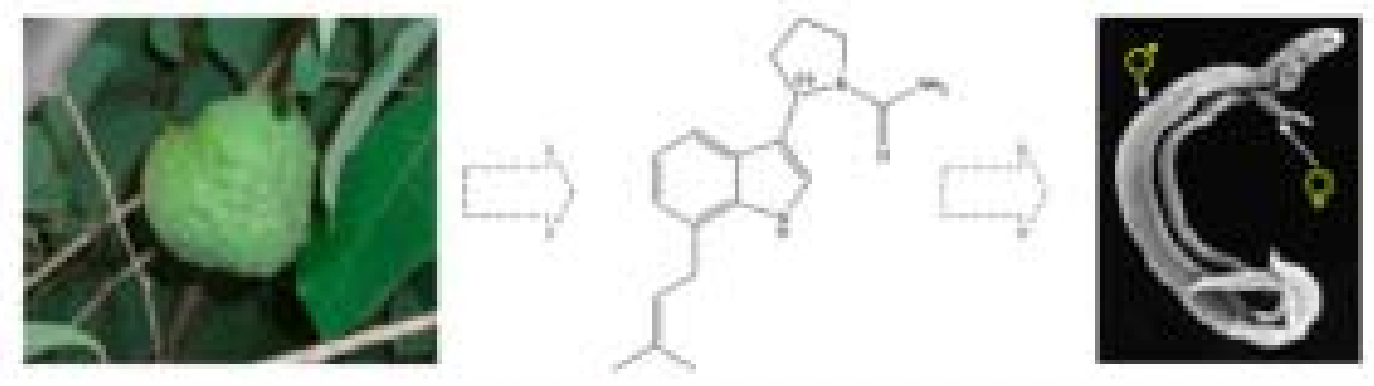
Figure 1. Chemical structures of compounds 1-5.
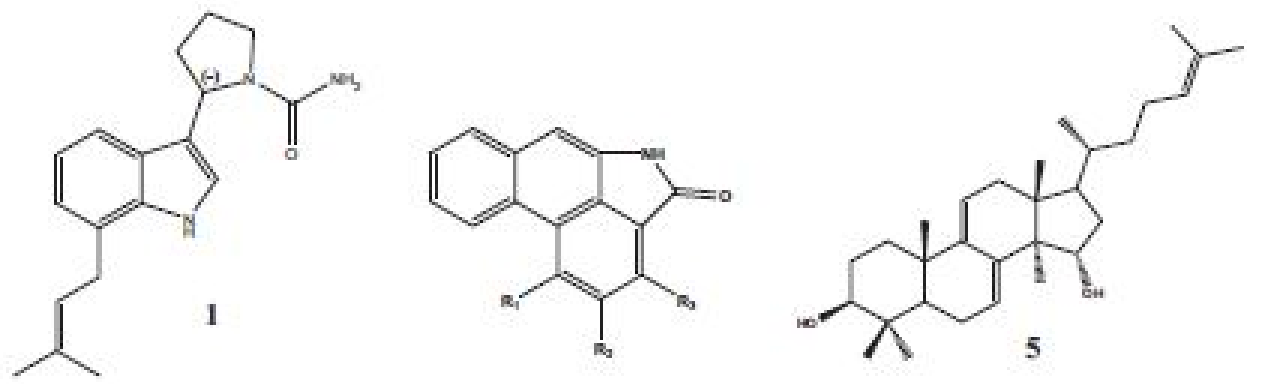

$$
\begin{aligned}
& 2 \mathrm{R}_{1}=\mathrm{OCH}_{3} ; \mathrm{R}_{2}=\mathrm{OH} ; \mathrm{R}_{3}=\mathrm{H} \\
& 3 \mathrm{R}_{1}=\mathrm{OCH}_{3} ; \mathrm{R}_{2}=\mathrm{OCH}_{3} ; \mathrm{R}_{3}=\mathrm{H} \\
& 4 \mathrm{R}_{1}=\mathrm{OCH}_{3} ; \mathrm{R}_{2}=\mathrm{OCH} ; \mathrm{R}_{3}=\mathrm{OH}
\end{aligned}
$$




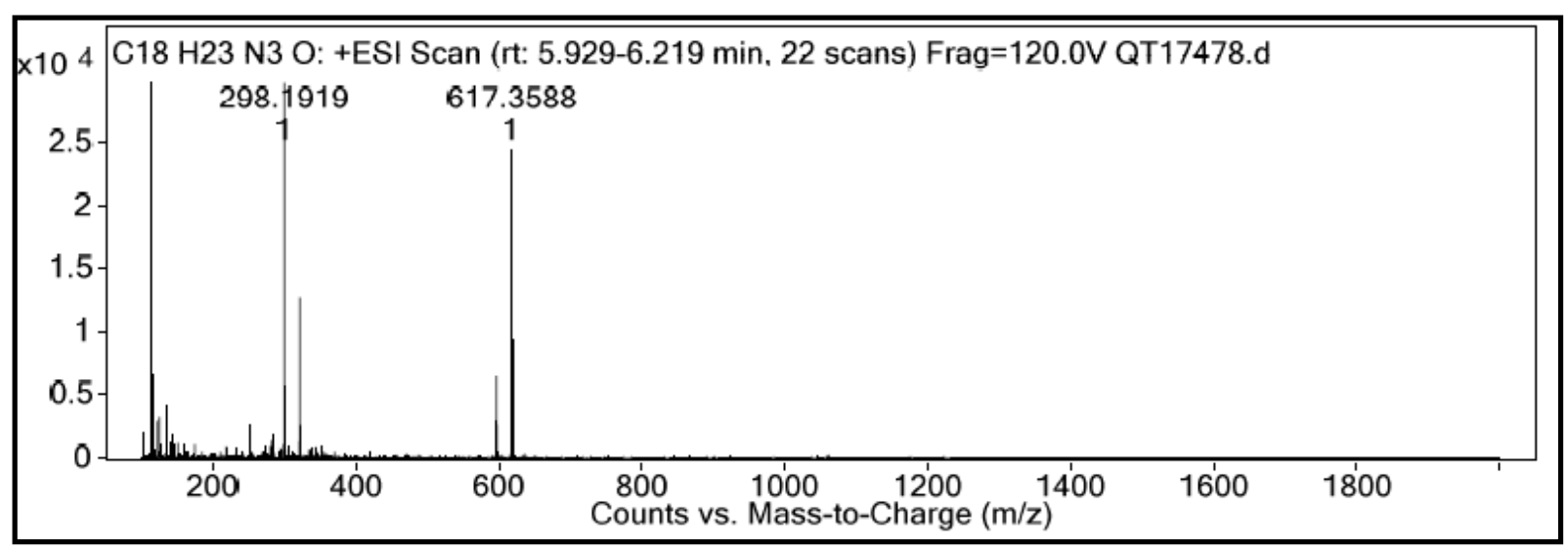

\section{HRESI-MS of Compound 1}

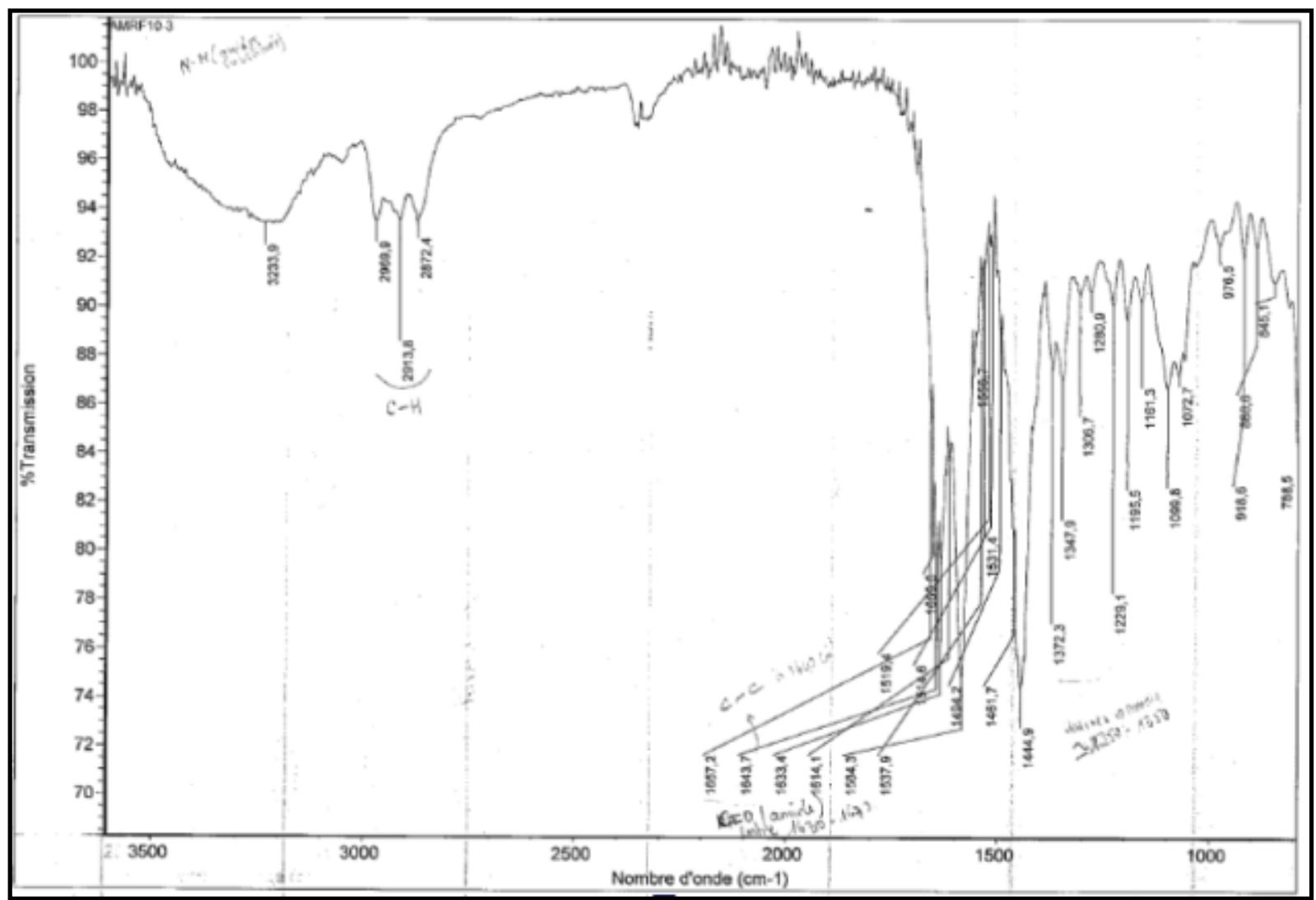

\section{IR Spectrum of Compound 1}

\section{ALPHA-D of Compound 1}

[Data Information]

Creation Date 28/06/2019 15:57

[Measurement Information]
[Comment]

Sample name

Comment

User 
Instrument Name

Model Name

Serial No.

Polarizer

Faraday Cell

Accessory

Accessory S/N

Temperature

25.00 C Control

Sonsor Holder

Monitor Sensor

Holder

Start Mode

Light Source

Keep target temperature $+/-0.10 \mathrm{C}$ while 5 seconds

$\mathrm{Na}$

Monitor wavelength 589

nm

D.I.T.

$31 \mathrm{sec}$ No. of

cycle 5

Cycle interval 10

sec Temp. Monitor

Holder Temp. Corr.

Factor None

Aperture(S)

8.0mm Aperture(L)

Auto

Mode

Specific O.R. Path

Length $\quad 10 \mathrm{~mm}$

Concentration $\quad 0.4$

$\mathrm{w} / \mathrm{v} \%$

Water content of sample

$0 \%$ Factor

\begin{tabular}{|l|l|l|l|l|l|}
\hline No. & Sample Name & Measurement Date & PMT Voltage[V] & Temperature[C] & Optical Rotation Monitor \\
\hline 1 & 3 & & & & -0.0150 \\
\hline 2 & $3-1$ & $28 / 06 / 201915: 55$ & 243 & 24.99 & -0.0145 \\
\hline 3 & $3-2$ & $28 / 06 / 201915: 55$ & 244 & 25.00 & -0.0146 \\
\hline 4 & $3-3$ & $28 / 06 / 201915: 56$ & 243 & 25.02 & -0.0152 \\
\hline 5 & $3-4$ & $28 / 06 / 201915: 56$ & 243 & 24.97 & -0.0153 \\
\hline 6 & $3-5$ & $28 / 06 / 201915: 57$ & 244 & 25.02 & -0.0154 \\
\hline
\end{tabular}

\begin{tabular}{|l|l|l|l|l|l|l|l|}
\hline No. & Specific O.R. & Path Length[mm] & Concentration[w/v\%] & Water content[\%] & Factor & S.D. & C.V. \\
\hline 1 & -37.5000 & 10 & 0.4000 & 0 & 1 & 1.0458 & 2.7889 \\
\hline 2 & -36.2500 & & & & & & \\
\hline 3 & -36.5000 & & & & & & \\
\hline 4 & -38.0000 & & & & & & \\
\hline 5 & -38.2500 & & & & & & \\
\hline 6 & -38.5000 & & & & & & \\
\hline
\end{tabular}

Division

Company

Faculté de pharmacie

\author{
PTC-203 \\ A031561234 \\ P-2000 \\ Dichrom \\ Flint Glass
}




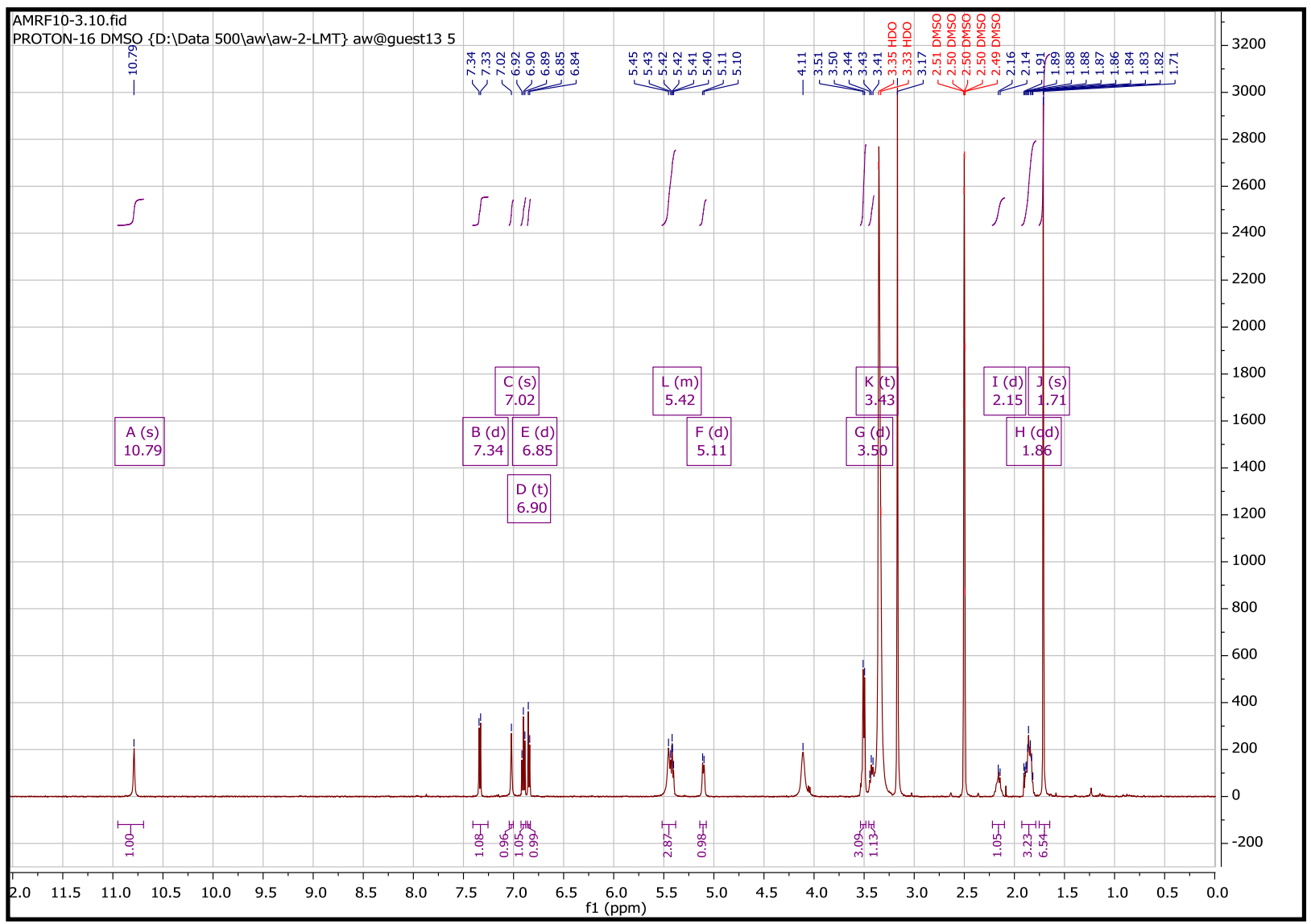

4. ${ }^{1}$ H NMR (500 MHz, DMSO-d6) spectrum of Compound 1 


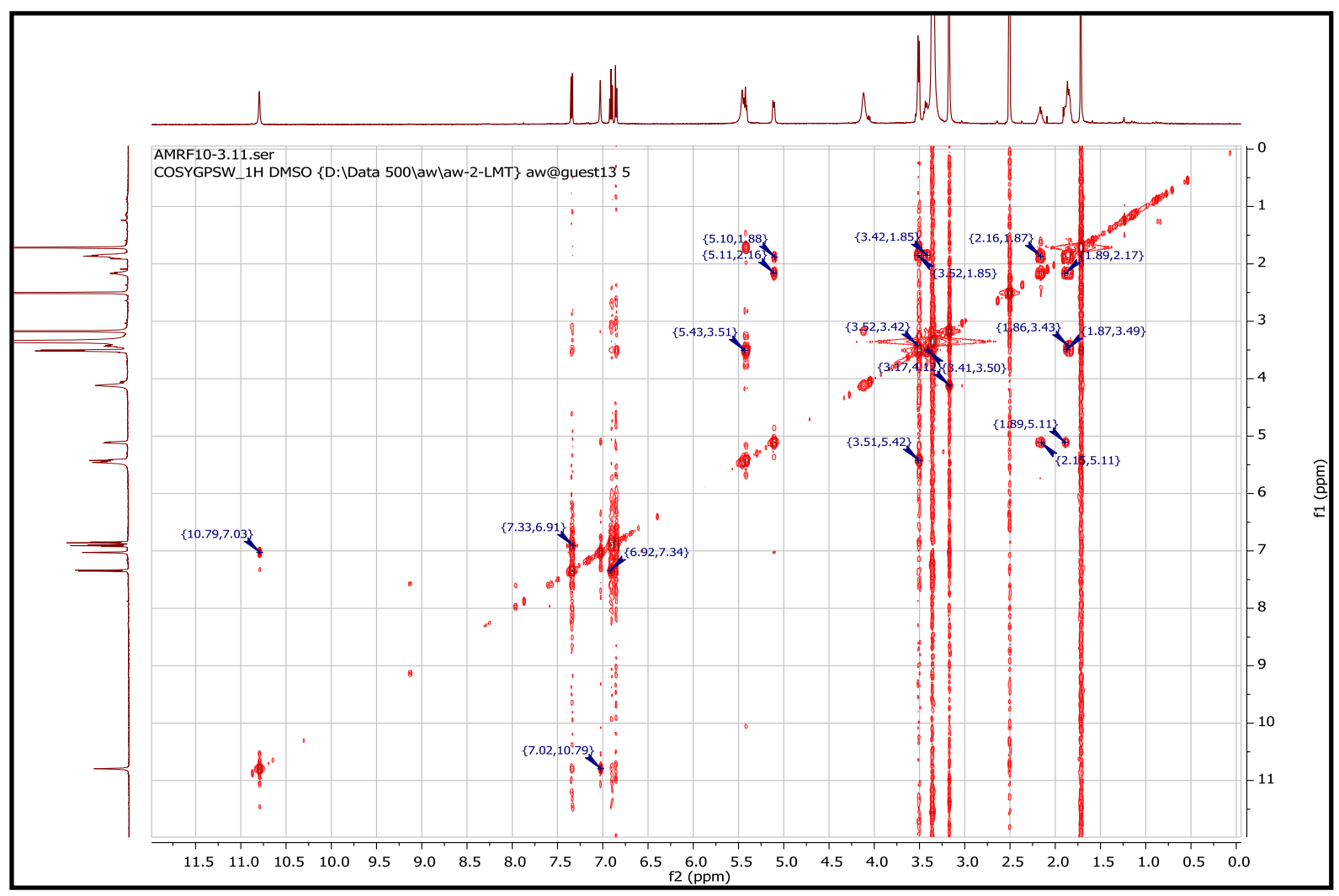

5. ${ }^{1} \mathrm{H}-{ }^{1} \mathrm{H} \operatorname{COSY}\left(500 \mathrm{MHz}\right.$, DMSO-d $\left.d_{6}\right)$ Spectrum of Compound 1

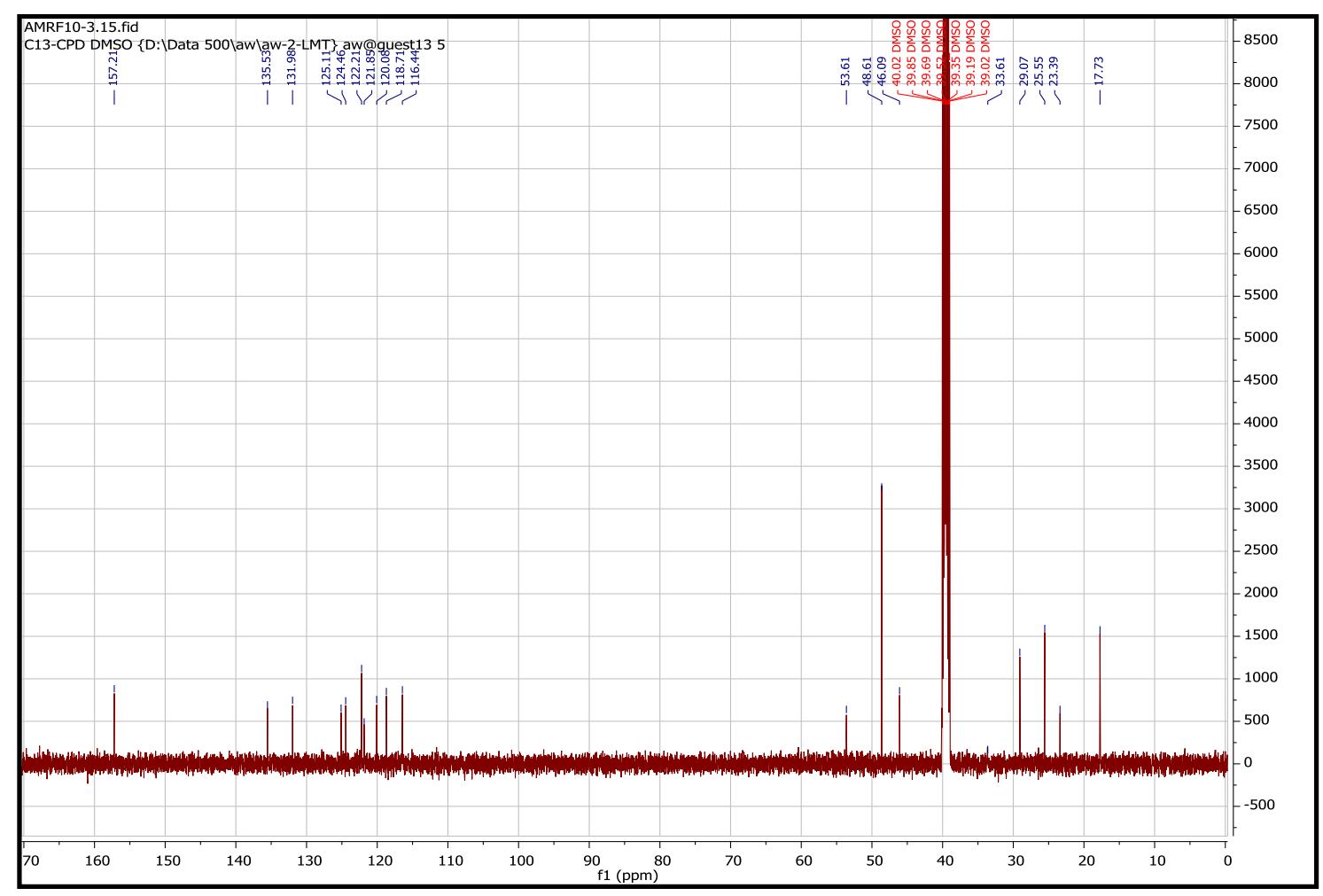

6. ${ }^{13} \mathrm{C}$ NMR (125 MHz, DMSO-d $\left.d_{6}\right)$ spectrum of Compound 1 


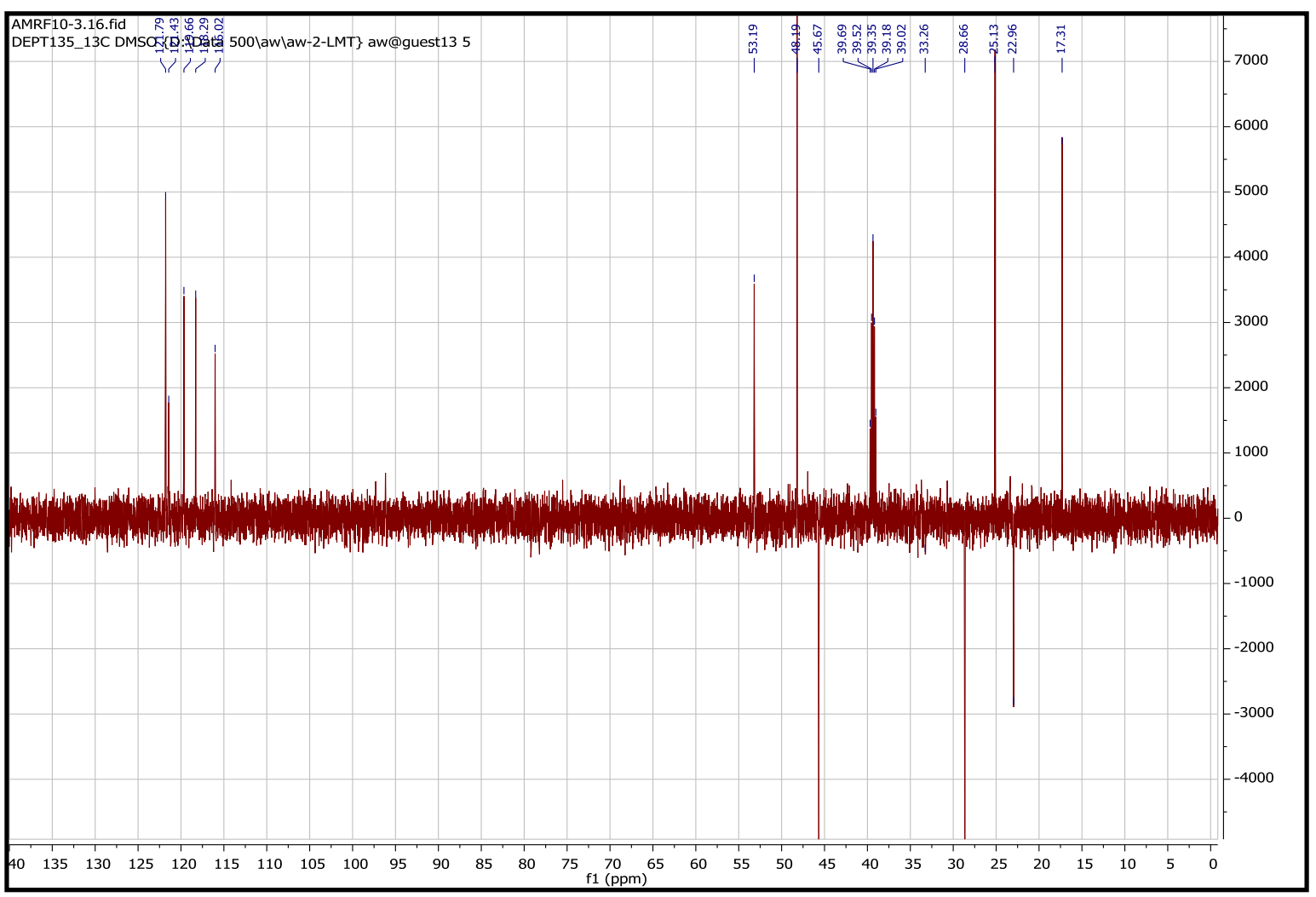

\section{DEPT 135 Spectrum of Compound 1}

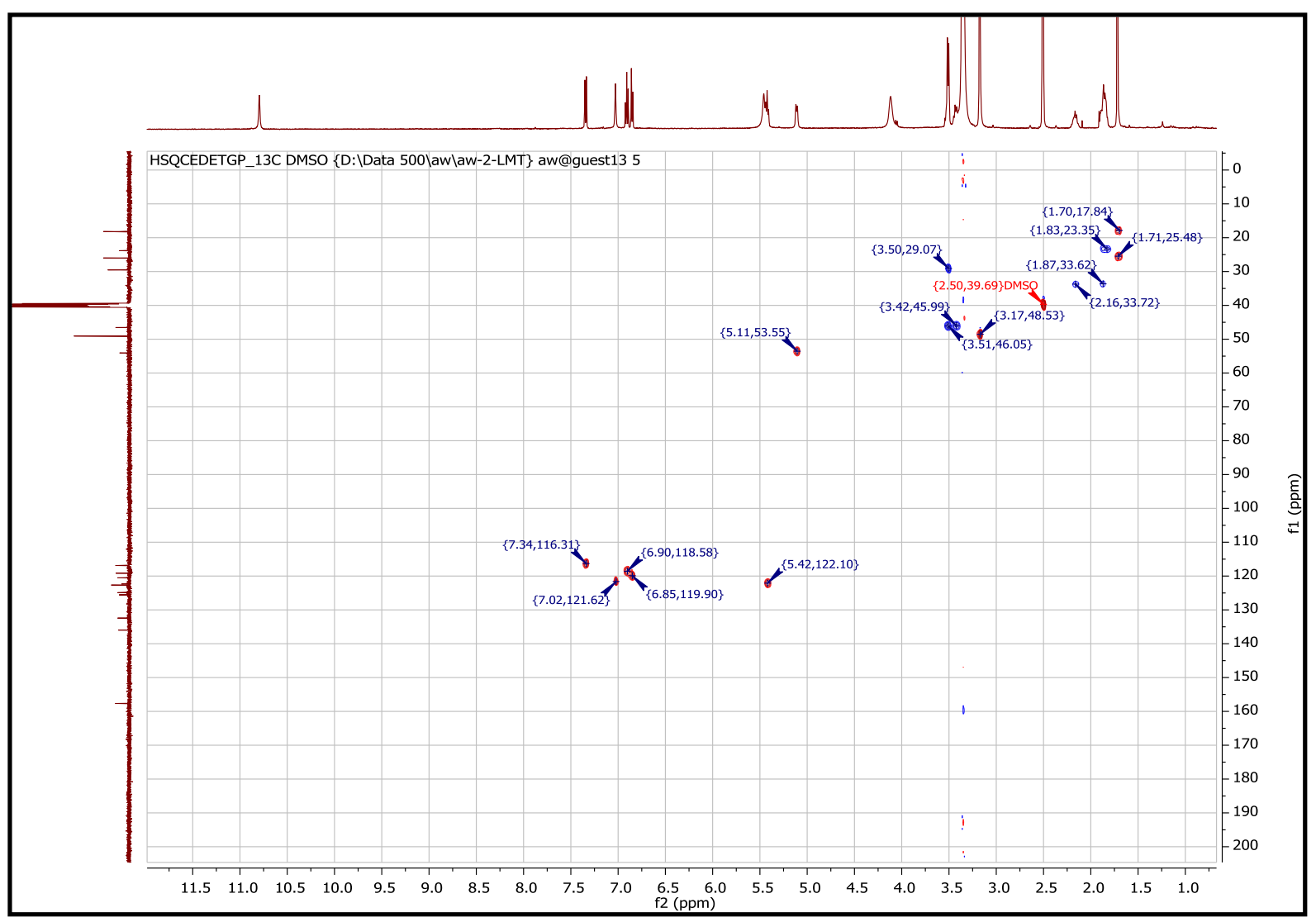

\section{HSQC Spectrum of Compound 1}




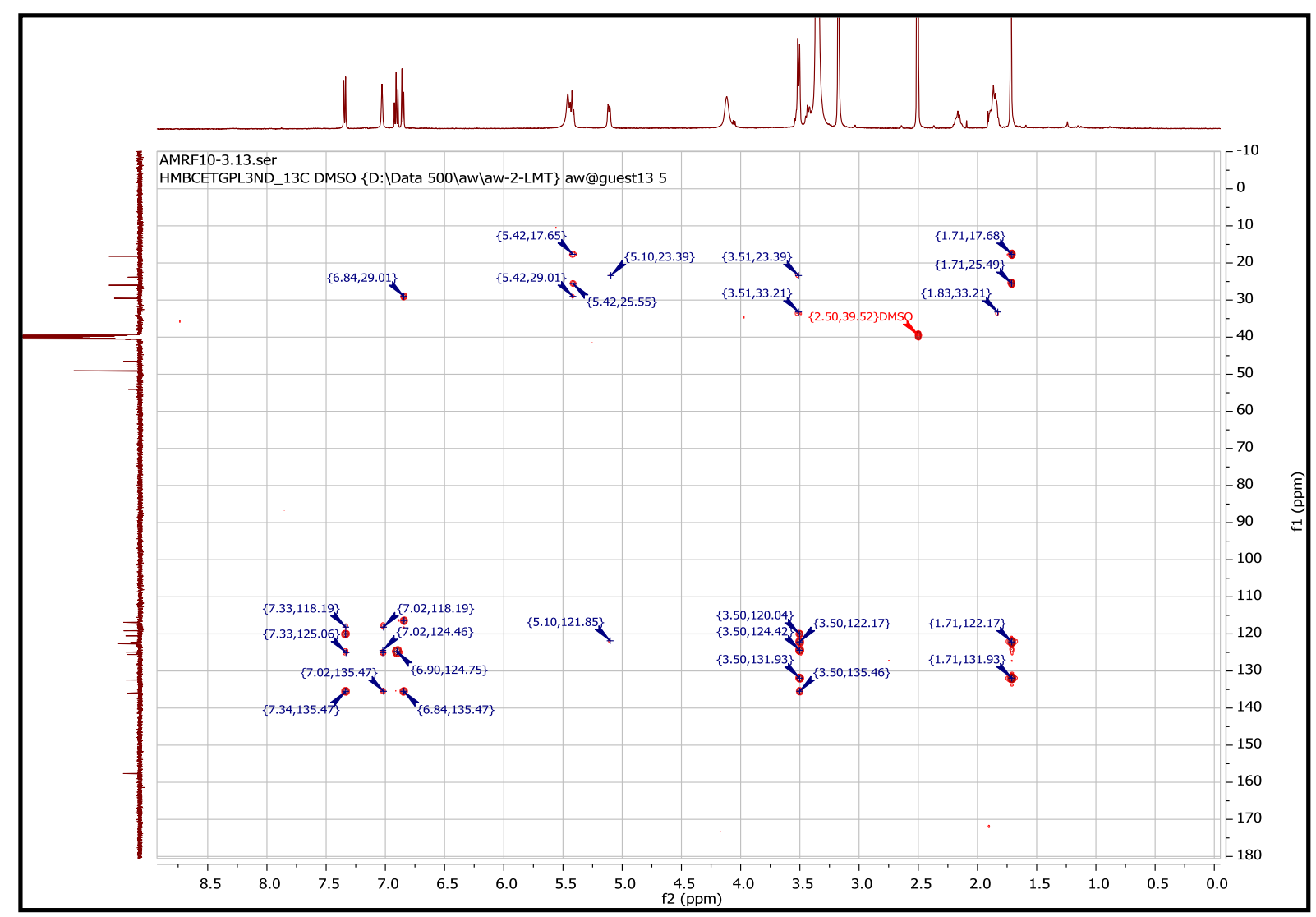

\section{HMBC Spectrum of Compound 1}

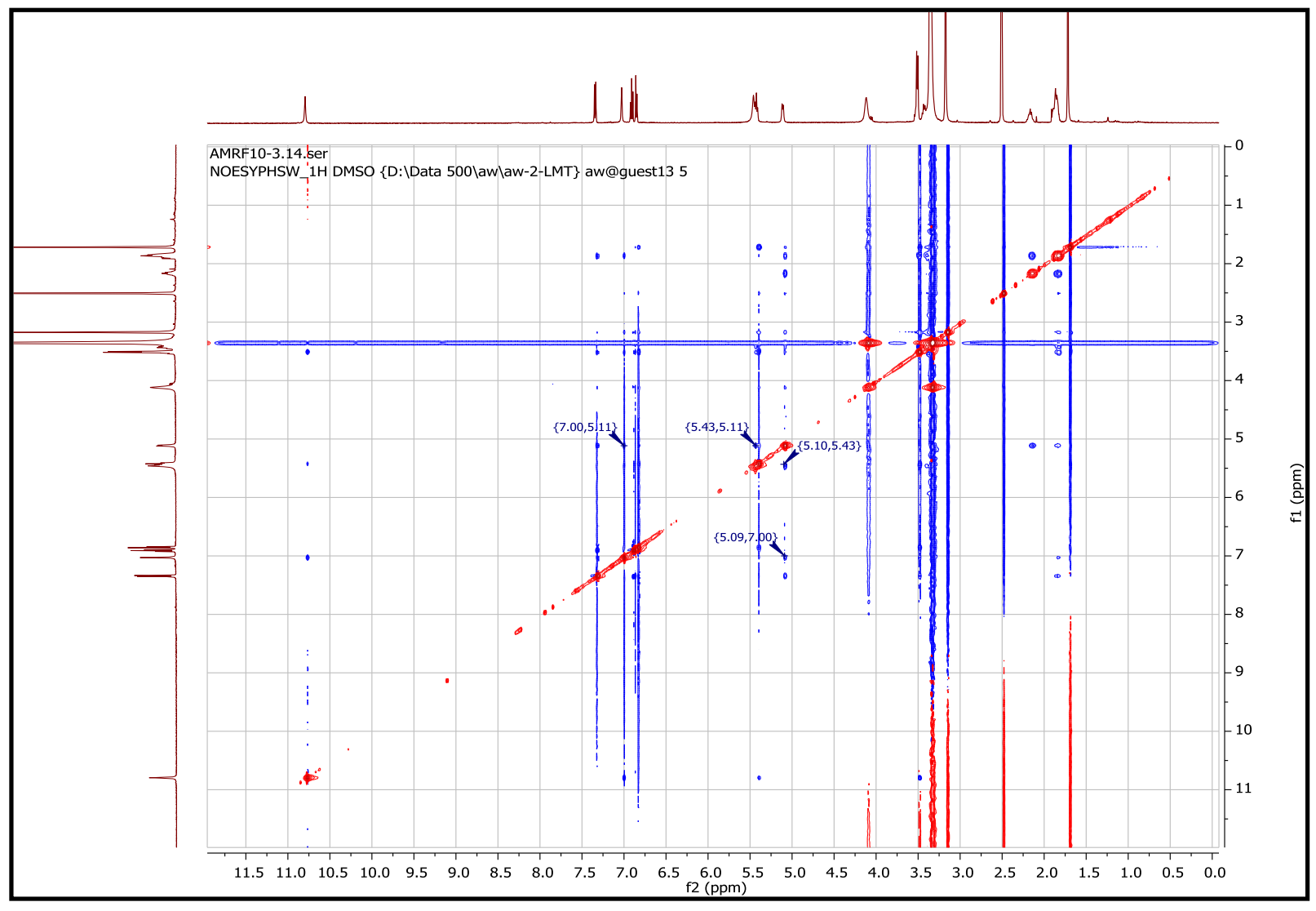

NOESY Spectrum of Compound 1 

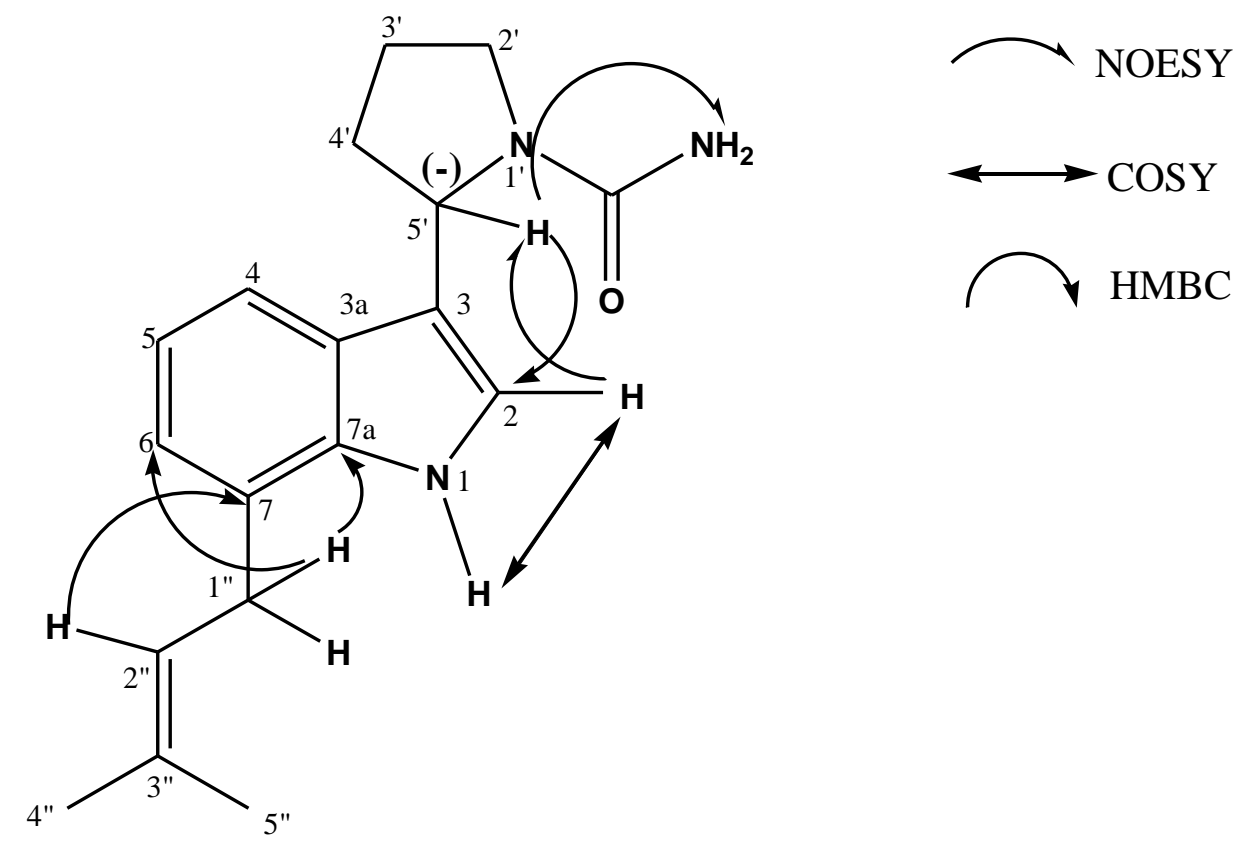

Figure S2. Key HMBC, COSY and NOESY Correlations between indole moiety and the two substituents of $\mathbf{1}$.
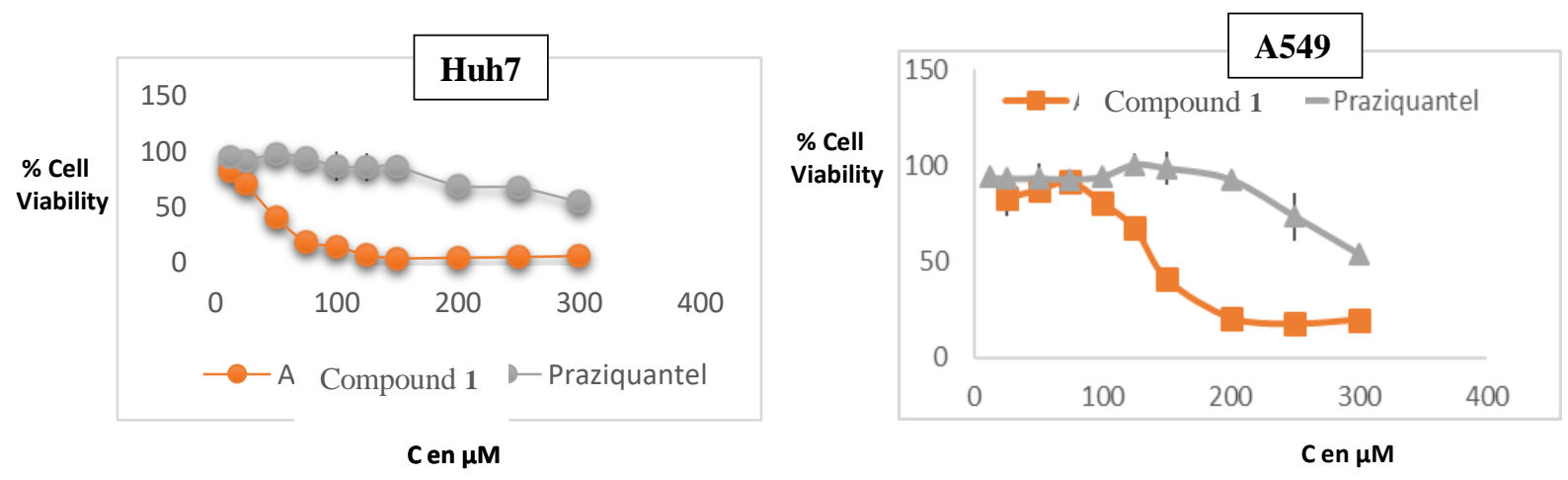

Figure S3. The cell viability of Compound $\mathbf{1}$ and Praziquantel assayed by MTT. 
Table S1. ${ }^{13} \mathrm{C}(125 \mathrm{MHz})$ and ${ }^{1} \mathrm{H}$ NMR (DMSO- $\left.d_{6}, 500 \mathrm{MHz}\right)[J(\mathrm{~Hz}), \delta(\mathrm{ppm})]$ data for compound (1).

\begin{tabular}{|c|c|c|}
\hline \multirow[t]{2}{*}{ Attributions } & \multicolumn{2}{|r|}{1} \\
\hline & $\delta^{13} \mathrm{C}$ & $\delta^{\mathrm{I}} \mathrm{H}(\mathrm{nH}$, mult., $J(\mathrm{~Hz}))$ \\
\hline 1 & - & $10.79(1 \mathrm{H}, \mathrm{s})$ \\
\hline 2 & 121.8 & $7.02(1 \mathrm{H}, \mathrm{s})$ \\
\hline 3 & 117.8 & - \\
\hline $3 a$ & 125.1 & - \\
\hline 4 & 116.4 & $7.34(1 \mathrm{H}, \mathrm{d}, J=7.5)$ \\
\hline 5 & 118.7 & $6.90(1 \mathrm{H}, \mathrm{t}, J=7.5)$ \\
\hline 6 & 119.7 & $6.85(1 \mathrm{H}, \mathrm{d}, J=7.5)$ \\
\hline 7 & 124.5 & - \\
\hline $7 \mathrm{a}$ & 135.5 & - \\
\hline $\mathrm{N}-\mathrm{CO}-\mathrm{NH}_{2}$ & 157.2 & $5.45(2 \mathrm{H}, \mathrm{s})$ \\
\hline \multirow[t]{2}{*}{2 ' } & 46.1 & $3.43(1 \mathrm{H}, \mathrm{m})$ \\
\hline & & $3.51(1 \mathrm{H}, \mathrm{m})$ \\
\hline $3^{\prime}$ & 23.4 & $1.86(2 \mathrm{H}, \mathrm{m})$ \\
\hline \multirow[t]{2}{*}{4 ' } & 33.7 & $1.89(1 \mathrm{H}, \mathrm{m})$ \\
\hline & & $2.17(1 \mathrm{H}, \mathrm{dd}, J=13.4 ; 6)$ \\
\hline 5 & 53.6 & $5.11(1 \mathrm{H}, \mathrm{bd}, J=7.2)$ \\
\hline $1^{\prime \prime}$ & 29.1 & $3.50(2 \mathrm{H}, \mathrm{d}, J=7.4)$ \\
\hline \multirow[t]{2}{*}{$2^{\prime \prime}$} & 122.2 & $5.43(1 \mathrm{H}, \mathrm{dd}, J=16.1$ \\
\hline & & $8.7)$ \\
\hline $3 "$ & 131.9 & - \\
\hline $4 "$ & 25.6 & $1.71(3 \mathrm{H}, \mathrm{s})$ \\
\hline $5^{\prime \prime}$ & 17.7 & $1.71(3 \mathrm{H}, \mathrm{s})$ \\
\hline
\end{tabular}

Assignments were based on HSQC, HMBC, COSY and NOESY experiments. 
Table S2.Effects of the extract and the isolated compounds on adult Schistosoma mansoni in vitro.

\begin{tabular}{|c|c|c|}
\hline $\begin{array}{l}\text { Extract/Compound } \\
\text { (No.) }\end{array}$ & $\begin{array}{l}\text { Concentration } \\
(\mu \mathrm{M})\end{array}$ & $\begin{array}{l}\text { Mobile worm } \\
\text { after } 6 \text { hours of } \\
\text { incubation } \\
(\%)\end{array}$ \\
\hline \multirow[t]{3}{*}{ Roots extract } & 100 & 44.4 \\
\hline & 50 & 100 \\
\hline & 10 & Not Done \\
\hline \multirow[t]{3}{*}{1 Manniindole } & $100^{*}$ & 70 \\
\hline & $50 *$ & 95 \\
\hline & $10^{*}$ & 100 \\
\hline \multirow[t]{3}{*}{2 Aristolactam AII } & 100 & 9.1 \\
\hline & 50 & 66.7 \\
\hline & 10 & 71 \\
\hline \multirow[t]{3}{*}{3 Aristolactam BII } & 100 & 62.5 \\
\hline & 50 & 77.3 \\
\hline & 10 & 94.4 \\
\hline \multirow[t]{3}{*}{ Praziquantel } & 100 & 0 \\
\hline & 50 & 7 \\
\hline & 10 & Not Done \\
\hline Control (RPMI) & - & 100 \\
\hline
\end{tabular}

*Experiments were performed twice. The others were performed three times. For each experiment, 10-12 worms were used with equilibrated sex-ratio. 
Table S3. Approximate $\mathrm{IC}_{50}$ values for the inhibition of $S m$ NACE by compounds.

The roots extract was active on $S m$ NACE with inhibition rate of $76.13 \%$. at C $=100 \mu \mathrm{g} / \mathrm{mL}$ being a mixture of compounds, its $\mathrm{IC}_{50}$ could not be determined.

\begin{tabular}{|l|l|}
\hline $\begin{array}{l}\text { Compound } \\
\text { (No.) }\end{array}$ & IC $_{\mathbf{5 0}}(\boldsymbol{\mu M})$ \\
\hline $\mathbf{1}$ & $>100$ \\
\hline $\mathbf{2}$ & $>100$ \\
\hline $\mathbf{3}$ & $>100$ \\
\hline $\mathbf{4}$ & $10-20$ \\
\hline Cyanidin* & 2.3 \\
\hline Delphinidin* & 6.0 \\
\hline
\end{tabular}

*Cyanidin and Delphinidin are the natural products reference SmNACE inhibitors (Kuhn et al. 2010). 